\title{
Microcystin Contamination in Sea Mussel Farms from the Italian Southern Adriatic Coast following Cyanobacterial Blooms in an Artificial Reservoir
}

\author{
De Pace Rita, ${ }^{1}$ Vita Valeria, ${ }^{1}$ Bucci Maria Silvia, ${ }^{2}$ Gallo Pasquale, ${ }^{3}$ and Bruno Milena ${ }^{4}$ \\ ${ }^{1}$ Department of Foggia, Experimental Zooprophylactic Institute of Puglia and Basilicata Regions, Via Manfredonia, \\ 20-71121 Foggia, Italy \\ ${ }^{2}$ Department of Campobasso, Regional Environment Protection Agency of Molise Region, Via Ugo Petrella, 1-86100 Campobasso, Italy \\ ${ }^{3}$ Department of Naples, Experimental Zooprophylactic Institute of Southern Italy, Via della Salute, 2-80055 Portici, Italy \\ ${ }^{4}$ Department of Environment and Primary Prevention, Istituto Superiore di Sanità, Viale Regina Elena, 299-00161 Rome, Italy
}

Correspondence should be addressed to Bruno Milena; mbruno@iss.it

Received 17 May 2013; Revised 4 September 2013; Accepted 11 November 2013; Published 12 January 2014

Academic Editor: Felipe Garcia-Rodriguez

Copyright (C) 2014 De Pace Rita et al. This is an open access article distributed under the Creative Commons Attribution License, which permits unrestricted use, distribution, and reproduction in any medium, provided the original work is properly cited.

\begin{abstract}
An experimental study was performed in 2009-2010 to investigate the polluting effect of eutrophic inland waters communicating with the sea coast. The study was planned after a heavy and long-lasting Planktothrix rubescens bloom occurred in the Lake Occhito, an artificial reservoir. The waters of the reservoir flow into the southern Adriatic Sea, near several marine breeding of Mytilus galloprovincialis mussels, a typical seafood from the Apulia region (Southern Italy). A monitoring study of water and mussels from the sea coast of northern Apulia region and on the Occhito reservoir was carried out over twelve months, to get more information regarding the contamination by cyanobacteria and related cyanotoxins. Elisa immunoassay analyses estimated total microcystin amounts from 1.73 to $256 \mathrm{ng} / \mathrm{g}$ in mussels, up to $0.61 \mu \mathrm{g} / \mathrm{L}$ in sea water and up to $298.7 \mu \mathrm{g} / \mathrm{L}$ in lake water. Analyses of some samples of free-living marine clams as well as of marine and freshwater fish proved microcystin contamination. Selective confirmatory analyses by LC/ESI-Q-ToF-MS/MS on some mussel samples identified the microcystin desMe-MC-RR as the major toxin; this compound has been reported in the literature as a specific marker toxin of Planktothrix rubescens blooms. Our study describes for the first time the direct relationship between environmental pollution and food safety, caused by seafood contamination from freshwater toxic blooms.
\end{abstract}

\section{Introduction}

Most poisoning risks from cyanobacteria blooms are due to microcystins (MC), a group of cyclic heptapeptides causing acute and chronic effects derived from their endocellular activity and protein phosphatase inhibition. Microcystins are hepatotoxins [1-6] acting as specific inhibitors of protein phosphatases 1, 2A [4], 3 (MC-LA) [7], 4 and 5 [8], and to a minor extent PP 2B [9]. They dephosphorylate serine and threonine residues in animals and plants. The inhibition of PP1 and PP2A increases the phosphorylation of proteins in liver cells, affecting several processes like metabolism, cell contractility, membrane transport, secretion, cell division, and gene transcription and translation.
MCs are responsible for liver failure and death in humans $[3,10]$, wild animals, livestock, and aquatic life [11, 12]. Hepatotoxic [3, 4] endocrine disrupting [13-17] and oncogene activating [18] effects have been described for these toxins, classified as 2B compounds in the IARC oncogenic scale [19]. Indirect evidence supporting tumour promotion of human cancer from exposure to MCs is derived from the studies of Yu [20], Ueno et al. [21], and Zhou et al. [22] in China, Fleming et al. [23] in Florida, and Svirčev et al. [24] in Serbia. MCs have synergic effects too, well documented in experimental studies on mice [25]. In these studies, daily subacute doses of MCs, administered intranasally to mice for 7-day periods, caused pathologic effects two times stronger than those produced by the sum of the MCs administered 
as a single dose. Bioaccumulation has been proposed to be responsible for this effect [26]. Several large scale fish death outbreaks have been associated to massive occurrence of cyanobacteria in water bodies [27-29].

Studies on fish contaminations showed species-specific sensitivities to microcystins; the uptake of these cyanotoxins in fish results primarily from oral ingestion and to a minor extent from absorption via the gill epithelium [30]. The toxicity of microcystins in fish depends on the balance between accumulation and metabolism [31], and the observed speciesspecific sensitivities have been interpreted as the result of anatomical, physiological, and behavioural differences and detoxification capacities via the glutathione-S-transferase pathway among the various fish orders [32-34].

In the past, health risks for consumers from gutted fish were traditionally considered negligible, because liver was considered the main target for bioaccumulation of microcystins. Recent studies, however, detected significant concentrations of microcystins in the muscle of wild and farmed fish, at $337.3 \mu \mathrm{g} / \mathrm{kg}$ in Tilapia rendalli [35], $102 \mu \mathrm{g} / \mathrm{kg}$ in Oreochromis niloticus [36], $96.5 \mu \mathrm{g} / \mathrm{kg}$ in Hypophthalmichthys molitrix [37], and $28 \mathrm{~g} / \mathrm{kg}$ in Oncorhynchus mykiss [38]; it should be noted that the WHO recommended a TDI of $0.04 \mu \mathrm{g} / \mathrm{kg}$ human body weight/day, indicating that even the consumption of fish muscle might represent a threat for human health. In Italy, 155 samples of fish and crustaceans collected in five contaminated lakes were analyzed, showing microcystin contamination levels from $0.21 \mu \mathrm{g} / \mathrm{kg}$ up to $14.6 \mathrm{mg} / \mathrm{kg}$ [39]. The possibility that microcystins accumulate in wild freshwater mussels was extensively documented [4045]. Several studies demonstrated the presence of microcystins in estuarine waters of eutrophic rivers and in tributary rivers from eutrophic lakes [46, 47]. Risks of wild marine mussel contamination were hypothesized, but laboratory studies were performed only about bioaccumulation models in marine common bivalves like M. galloprovincialis [48-51].

Metabolites present in toxic cyanobacterial cells may decrease the glutathione-S-transferase (GST) detoxification activity in $M$. galloprovincialis mussel during accumulation; as a consequence, toxins may be detected in mussels at early contamination step, even one day after the beginning of cell assumption. The GST activity increases in the depuration period, when the contact with the cyanobacteria is depressed, causing a periodic (every 4 days) rise of microcystin levels in tissues, due to the renewal of PPases and to the subsequent release of unbound toxins [52]. In spite of initial GST inhibition, which could have been developed by toxic cyanobacteria to cause predator death by fast and high toxin accumulation, $M$. galloprovincialis physiology seems quite resistant to microcystin contamination, with low or no mortality observed in laboratory experiments $[46,49]$. The resistance could be due to the ability of the organism to detect and repeal the cyanobacterial toxic cells through the labial palps, sensory and photoreceptive tentacles, which entangle the suspended food and direct it to the mouth [53]. In the same experiments the mussels showed a quite long depuration period, ranging from 11 to 14 days, that could cause possible transfer along the food chain [46].
The occurrence of freshwater toxic blooms in eutrophic river estuaries and harbours is known [2, 35, 54]. Consequent risks of marine fauna (fish, crayfish, and molluscs) contamination have been hypothesized and investigated in laboratory experiments [41, 47, 49]. In 2010 several sea otters, a protected species of coastal marine mammals, were found out dead because of microcystin intoxication in the Monterey Bay [47]. These deaths were possibly due to the assumption of preys (molluscs and crayfish) contaminated by toxic blooms, discharged in the ocean by three nutrientimpaired rivers, tributaries of eutrophized Californian lakes. Unfortunately, the wild preys of otters were not available for sampling and analysis for microcystin contamination in that occurrence. Therefore, no direct relationship was possible between cyanobacteria blooms in lakes and marine fauna intoxications. A recent study on wild $M$. galloprovincialis from Amvrakikos Gulf (Greece) showed microcystin accumulation, due to local toxic blooms of the euryhaline cosmopolitan species Synechococcus sp. and Synechocystis sp. [55]. In a review, the same author refers to possible contamination of mussel sea breeding because of wastes in the ocean of microcystins, produced in upstream freshwater lakes and reservoir. Suspected cases in northwestern Pacific and eastern Canadian coast have been also reported [56].

In 2009 a heavy and long-lasting toxic bloom of Planktothrix rubescens occurred in the Occhito drinking water basin, causing serious management problems [57]. Video shots from helicopter flights showed reddish thick scum floating along the emissary River Fortore down to the sea. This study was performed to detect possible toxin contaminations in the breeding of Mytilus galloprovincialis along the sea coast; these mussels represent an appreciated seafood production, very important for the economy of the Apulia region.

\section{Materials and Methods}

2.1. The Study Site. Lake Occhito, situated at the boundaries between the two Italian regions Molise and Apulia, is the largest artificial reservoir in Italy. Created for drinking purposes by damming the River Fortore, its mean depth is $90 \mathrm{~m}$, its surface area is $13 \mathrm{~km}^{2}$, and its long axis is $12 \mathrm{~km}$. The distance of the river to reach the sea is about $67 \mathrm{~km}$. The river below the dam maintains the same name Fortore and reaches the Apulia northern coast, close to important sea mussel farms, which are located also in two coastal lagoons, the so-called Lesina and Varano Lakes (Figure 1).

In winter 2009, an extended Planktothrix rubescens bloom completely covered the surface of Lake Occhito with thick red scums, from January to April. In the past years, red blooms in the lake were occasionally observed by eyewitnesses. In January the bloom covered the entire surface of the lake and in the following months reached the entire water supply network of the neighbouring territories. In 2009 March and April, after a series of heavy rainfall events, the bulkheads of the Fortore Dam were opened to let the waters flow into the river below, lowering the dangerously high level of the lake. Some videos taken from helicopter flights showed red scums flowing through the dam towards the sea, along the Fortore 


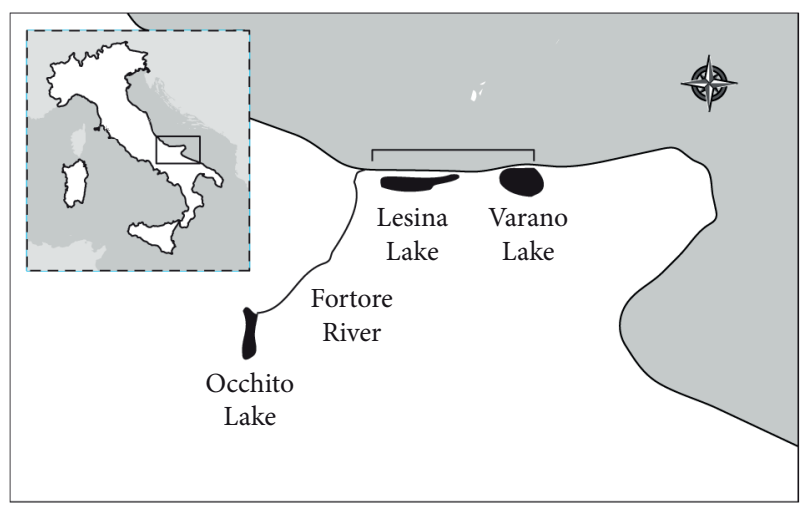

FIGURE 1: Map of the study site location in southern Adriatic Sea. The marine stations were distributed along the Apulia northern coast before the Lesina and Varano lagoons; the prevailing ocean currents flow from west to east.

River. The freshwater "red tide" reached the Adriatic Sea from Lake Occhito floating downstream the River Fortore.

2.2. Sample Collection. A total of 267 samples were collected for the study: 144 water samples from 3 stations in the lake (the sampling depths were $0,25 \mathrm{~m}$ ) were withdrawn monthly, using a 2.51 Ruttner bottle, from April 2009 to July 2010; 5 fish samples $(300 \pm 50 \mathrm{~g}$ mean body weight, $2-3$ years of age) from the 3 stations in the lake and 1 station on the sea in May 2009; 75 mussel samples (sample size approximately $200 \mathrm{~g}$ ), 7 clam samples (sample size approximately $200 \mathrm{~g}$ ), and 36 sea water samples (sample size 2 L) from April 2009 to July 2009 and from January 2010 to July 2010 were collected in 60 surface stations from 13 coastal mussel farms along $30 \mathrm{~km}$ of coastline (from Lesina to Varano farm acronyms: L1 PN, L2 PN, L3, I1, TM1, TM2, TM3, CV1, CV2, CV3, CV4, CV5, and CV6), $100 \mathrm{~m}$ away from the sea shore (minimum 1 station/farm, maximum 20 stations/farm, and distance between stations about $50 \mathrm{~m}$ ). The mussel farms are located near the Fortore River mouths, before the coastal harbours (called lakes) Lesina and Varano (Apulia region, Southern Italy) (Figure 1). By fishing, 3 carps (Cyprinus carpio) were collected from the lake, one of them being freshly dead near the lakeshore) while 1 bogue (Boops boops) and 1 mackerel (Scomber japonicus colias) were withdrawn from the sea. All fish were quickly killed with a precise blow to the head, transported to the laboratory, and dissected. In the sample collection, the capture of a few fish from lake and sea ichthyic fauna was carried out, for preliminary analysis, to monitor the presence of microcystin contamination. No samplings could be performed along the river. Although the aim of this study was not the screening of the lake, analyses of total phosphorus (TP) were performed on all the lake samples, in order to reach a preliminary classification of its trophic state [58]. Analyses of microcystin content and cell count were performed on some lake samples.

2.2.1. Microscopic Observation. The sea water samples were stored in freezing boxes and transported to the laboratory. Subsamples were preserved in 1\% Lugol's solution and analyzed by an inverted microscope (Leitz Labovert FS), according to Utermöhl [59] and Lund et al. [60], using $25 \mathrm{~mL}$ sedimentation chambers for phytoplankton identification and cell density estimation. A single sample of lake water was analyzed for P. rubescens abundance.

2.3. Chemicals and Reagents. Microcystin-LR (MC-LR), microcystin-YR (MC-YR), microcystin-RR (MC-RR), microcystin des- methyl-RR (desMe-MC-RR), and microcystin des-methyl-LR (desMe-MC-LR) were supplied by DHI Water and Environment (Denmark); microcystin-LF (MCLF) and microcystin-LW (MC-LW) were supplied by VinciBiochem (Vinci, Italy) in screw capped vials containing $25 \mu \mathrm{g}$ standard. All the reference materials were of analytical grade purity. Trifluoroacetic acid (TFA), HPLC grade acetonitrile, methanol, and glacial acetic acid (99\%) were from Carlo Erba (Milan, Italy). HPLC grade water was produced using a MilliQ system (Millipore, Bedford, MA, USA). C18 endcapped (EC) solid-phase extraction (SPE) cartridges with $1 \mathrm{~g}$ sorbent bed and $6 \mathrm{~mL}$ reservoir volume (Isolute, $\mathrm{UK}$ ) were purchased from Step-Bio (Bologna, Italy). HLB SPE Waters OASIS cartridges were purchased by Waters, Milford, MA, USA.

2.3.1. Standard Solutions of MCs. MC-RR, MC-LR, MCYR, desMe-MC-RR, and desMe-MC-LR reference materials were purchased in standard stock solutions in methanol, at $10 \mu \mathrm{g} / \mathrm{mL}, 10 \mu \mathrm{g} / \mathrm{mL}, 6.3 \mu \mathrm{g} / \mathrm{mL}, 8.1 \mu \mathrm{g} / \mathrm{mL}$, and $7.1 \mu \mathrm{g} / \mathrm{mL}$, respectively. To prepare MC-LF and MC-LW standard stock solutions at $10 \mu \mathrm{g} / \mathrm{mL}$, the vial content $(25 \mu \mathrm{g})$ of each compound was dissolved in $2.5 \mathrm{~mL}$ methanol. A MCs mix standard solution at $2.5 \mu \mathrm{g} / \mathrm{mL}$, containing MC-RR, MC-LR, MC-LW, and MC-LF, was prepared by mixing equal volumes of each standard solution at $10 \mu \mathrm{g} / \mathrm{mL}$, while the MC-YR, desMe-MC-RR, and desMe-MC-LR standard stock solution were opportunely diluted in methanol to prepare a working solution at $2.5 \mu \mathrm{g} / \mathrm{mL}$. All the standard stock solutions were stable for at least six months if stored in the dark at $-20^{\circ} \mathrm{C}$. The mix working standard solutions of the seven MCs at 10, 25, 50, 75 , and $100 \mathrm{ng} / \mathrm{mL}$ were prepared daily from the standard mix solutions at $2.5 \mu \mathrm{g} / \mathrm{mL}$ by diluting with methanol.

2.3.2. Phosphorus Analyses. Analyses were carried out on lake water samples within $24 \mathrm{~h}$ after sampling, using a Perkin Elmer Lambda 25 UV/VS spectrophotometer, supported by a UV-WinLab software. Samples were digested in persulphate to dissolve organic and nonorganic particulate matter in suspension, as described by Lambert and Maher [61], prior to detection of total phosphorus (TP). TP was measured following the method of Murphy and Riley [62].

2.4. Extraction of Microcystins from Tissue. Five grams (wet weight) of muscle tissue from each fish was extracted. Shellfish sampled at every sampling station were treated as follows. The whole body of mussels (Mytilus galloprovincialis, about $4 \mathrm{~g}$ wet body weight) or clams (Venus gallina, about $3 \mathrm{~g}$ wet body weight) was homogenized. The homogenized individuals were pooled up to $100 \mathrm{~g}$ for each species, and $5.00 \pm 0.05 \mathrm{~g}$ 
of each pool was weighed. The sample was homogenized in $10 \mathrm{~mL} \mathrm{MeOH}$ for $15 \mathrm{~min}$. using an Ultra-Turrax T8 (IKA Werke, Staufen, Germany) grinder and then sonicated for $5 \mathrm{~min}$. at $30-40^{\circ} \mathrm{C}$ in an ultrasonic bath (Elgasonic Swiss made, $25 \mathrm{kHz}$ ) to disrupt cell membranes. The sample was centrifuged for $5 \mathrm{~min}$. at $5000 \mathrm{~g}$ and the supernatant decanted and filtered on a paper filter. The extraction was repeated on the pellet, the sample was centrifuged, and the supernatant filtered on the same filter previously used. The filter and the funnel were washed three times with little volumes of $\mathrm{MeOH}$; the two supernatants and the washings were gathered, then reduced to a small volume $(1-2 \mathrm{~mL})$ by rotary evaporator (Büchi, Switzerland) at $40^{\circ} \mathrm{C}$, and diluted to $5 \mathrm{~mL}$ with $\mathrm{MeOH}$. One $\mathrm{mL}$ (for fish) and $0.5 \mathrm{~mL}$ (for mussels and clams) of the extract (corresponding to $1 \mathrm{~g}$ of tissue) were then added with $1 \mathrm{~mL}$ of distilled water and loaded onto a HLB SPE Waters OASIS cartridge, preconditioned with $1 \mathrm{~mL} \mathrm{MeOH}$ followed by $1 \mathrm{~mL}$ of distilled water. The column was washed with $1 \mathrm{~mL}$ of $5 \% \mathrm{MeOH}$ in distilled water. Microcystins were eluted by $1 \mathrm{~mL}$ of $\mathrm{MeOH}$. The $\mathrm{MeOH}$ eluate was dried by rotary evaporator at $40^{\circ} \mathrm{C}$; the residue, dissolved in $2 \mathrm{~mL}$ distilled water, was stored at $-30^{\circ} \mathrm{C}$ for subsequent microcystin analysis with the EnviroGard Elisa kit.

2.4.1. Sample Clean-Up. Selected mussel samples from marine areas near the Lake Lesina in the province of Foggia, collected after the development of the $P$. rubescens bloom in Lake Occhito, were analyzed by ion trap LC/ESI-MS/MS. Fish muscle and mussels were homogenized by Ultra-Turrax; $5.00 \pm 0.01 \mathrm{~g}$ was weighed, extracted by shaking for $3 \mathrm{~min}$ with $20 \mathrm{~mL}$ of the mixture MilliQ water/methanol 1/3 v/v containing $0.1 \%$ trifluoroacetic acid (TFA), and then centrifuged at $1086 \mathrm{~g}$ for $10 \mathrm{~min}$. The upper liquid phase was separated and reduced to about $5 \mathrm{~mL}$ in rotary evaporator at $40^{\circ} \mathrm{C}$. Twenty $\mathrm{mL}$ MilliQ water was added, and the sample was loaded by gravity onto a SPE C18 end- capped cartridge, previously rinsed with $5 \mathrm{~mL}$ methanol and equilibrated with $5 \mathrm{~mL}$ MilliQ water. The cartridge was washed with $5 \mathrm{~mL}$ of MilliQ water/methanol 95/5 v/v and then dried under vacuum for $30 \mathrm{~min}$. The SPE column was eluted with $5 \mathrm{~mL}$ TFA $1 \%$ in methanol v/v; the sample was dried under a nitrogen stream at $40^{\circ} \mathrm{C}$ and then dissolved in $1 \mathrm{~mL}$ methanol and analyzed by ion trap LC/ESI- MS/MS.

2.5. Water Sample Extraction. The samples of sea water were directly analyzed with the EnviroGard Elisa Kit for microcystin detection. Microcystins standards were analyzed dissolved in water. Lake samples were centrifuged and the supernatants were filtered through G/C filters and analysed for extracellular MCs. Toxins were extracted from cyanobacteria pellets following the procedure described by Meriluoto and Eriksson [63]. Fresh aliquots of cyanobacteria biomass $(10-50 \mathrm{mg})$, obtained by centrifugation of water samples, were extracted two times with $2 \mathrm{~mL}$ portions of sterile distilled water. The solution was stirred, sonicated for $5 \mathrm{~min}$ at $30-40^{\circ} \mathrm{C}$ (Vibra-Cell, Sonics \& Materials Inc.), and then centrifuged for $10 \mathrm{~min}$ at $11.000 \mathrm{rpm}$ (Beckman, LT-55 Ultracentrifuge) to eliminate debris. The supernatant was then collected and the whole process repeated twice. The two supernatants were pooled and analyzed with the EnviroGard Elisa Kit.

\subsection{Microcystin Analysis}

2.6.1. ELISA Analysis. ELISA analyses were performed in triplicate using the Microcystins Plate EnviroGard Kit (Strategic Diagnostics Inc., Newark, DE, USA). The EnviroGard Kit is a direct competitive ELISA for quantitative detection of microcystins and nodularins (limit of quantification $0.1 \mathrm{ppb})$. It does not differentiate between microcystinLR and other microcystin variants but detects their presence to differing degrees. The concentrations at $50 \%$ inhibition $\left(50 \% \mathrm{~B}_{o}\right)$ for these compounds are microcystin-LR $0.31 \mathrm{ppb}$, microcystin-RR $0.32 \mathrm{ppb}$, and microcystin-YR $0.38 \mathrm{ppb}$. The final absorbances in the microplate of the kit were measured at $450 \mathrm{~nm}$ with an Anthos 2010 spectrophotometer (Anthos-Labtech, Salzburg, Austria). Elisa antibodies were successfully used to detect microcystins in organic matrices $[27,35,49,64]$. However, in this study tests were performed in order to prevent false positive/negative results [65]. Three mussel samples spiked with microcystin-LR at $1 \mu \mathrm{g} / \mathrm{g}$, three uncontaminated mussel samples plus three sea water samples spiked with microcystin-LR at $1 \mu \mathrm{g} / \mathrm{L}$, and three uncontaminated sea water samples were tested with the EnviroGard Kit. Uncontaminated mussel tissues and water samples showed negative results, below the cut-off of the ELISA kit; in mussel and water samples spiked with microcystin-LR average recovery rates of $87 \%$ and $90 \%$ were measured, respectively.

2.6.2. MALDI-ToF/MS Analysis. Mass spectrometry experiments were carried on by a Voyager DE-PRO time-offlight mass spectrometer (PerSeptiveBiosystems, Framingham, MA, USA) equipped with a $\mathrm{N}_{2}$ laser $(337 \mathrm{~nm}, 3 \mathrm{~ns}$ pulse width). $\alpha$-cyano-4-hydroxycinnamic acid was used as matrix. The sample $(1 \mu \mathrm{L}$ from a solution in water) was loaded onto the target and dried. Afterwards, $1 \mu \mathrm{L}$ of a mixture made of $10 \mathrm{mg} / \mathrm{mL} \alpha$-cyano-4-hydroxycinnamic acid in $0.1 \%$ TFA in $\mathrm{H}_{2} \mathrm{O}$ /acetonitrile $(1 / 1, \mathrm{v} / \mathrm{v})$ was added. For each sample, mass spectrum acquisition was performed in the positive linear or reflector mode accumulating 200 laser pulses. The accelerating voltage was $20 \mathrm{kV}$. External mass calibration was performed with low-mass peptide standards (PerSeptiveBiosystems, Framingham, MA, USA). The mass spectrometer was calibrated in the mass range $500-2500 \mathrm{~m} / \mathrm{z}$ using $1 \mu \mathrm{L}$ of standard Low Mass Range Peptide Mix (brand name mixl, Applied Biosystems, Monza, Italy); a resolution of 100.000 was calculated.

\subsubsection{LC/ESI-Q-ToF/MS-MS Analysis. LC/ESI-Q-ToF-MS/} MS spectra were performed by a quadrupole-time-of-flight (Q-ToF) Ultima hybrid mass spectrometer (Waters, Manchester, UK), equipped with an electrospray ion source (ESI) operating in the positive ion mode, and a nanoflow highpressure pump system model CapLC (Waters, Manchester, UK). Samples $(1 \mu \mathrm{L})$ were loaded onto a $5 \mathrm{~mm} \times 100 \mu \mathrm{m}$ 
TABLE 1: The experimental conditions and selected diagnostic ions for ion trap LC/ESI-MS/MS analysis.

\begin{tabular}{|c|c|c|c|c|c|c|c|}
\hline & \multicolumn{7}{|c|}{$\mathrm{MS} / \mathrm{MS}$} \\
\hline & MC-RR & desMe-MC-RR & MC-YR & MC-LR & desMe-MC-LR & MC-LW & MC-LF \\
\hline Ionization mode & negative & negative & negative & negative & negative & negative & negative \\
\hline Maximum injection time (ms) & 300 & 300 & 300 & 300 & 300 & 300 & 300 \\
\hline Isolation width $(\mathrm{m} / \mathrm{z})$ & 2 & 2 & 2 & 2 & 2 & 2 & 2 \\
\hline Molecular ion $(\mathrm{M}-\mathrm{H})^{-}(\mathrm{m} / z)$ & 1036.3 & 1022.3 & 1043.4 & 993.3 & 979.4 & 1023.5 & 984.5 \\
\hline MS/MS precursor ion $(\mathrm{M}-\mathrm{H})^{-}(m / z)$ & 1036.3 & 1022.3 & 1043.4 & 993.3 & 979.4 & 1023.5 & 984.5 \\
\hline Collision energy (\%) & 32 & 32 & 32 & 32 & 32 & 35 & 35 \\
\hline \multirow{4}{*}{$\begin{array}{l}\text { Selected diagnostic MS/MS ions }(m / z) \\
(\text { SRM) }\end{array}$} & 1036.5 & 1022.3 & 1043.4 & 993.3 & 979.4 & 1023.5 & 984.5 \\
\hline & 1018.4 & 1004.5 & 1025.3 & 975.4 & 961.3 & 1005.3 & 966.3 \\
\hline & 994.4 & 980.4 & 931.4 & 962.4 & 904.3 & 992.3 & 953.3 \\
\hline & & 962.4 & & & & & \\
\hline $\begin{array}{l}\text { Selected diagnostic MS/MS ions }(\mathrm{m} / z) \\
\text { (quantitative analysis) }\end{array}$ & 1018.4 & 1004.5 & 1025.3 & 975.4 & 961.3 & 1005.3 & 966.3 \\
\hline
\end{tabular}

i.d.Zorbax 300 SB C18 trap column (Agilent Technologies, USA), and MCs were separated on a $15 \mathrm{~cm} \times 100 \mu \mathrm{m}$ i.d. Atlantis $\mathrm{C} 18$ capillary column at $1 \mu \mathrm{L} / \mathrm{min}$ flow rate, using aqueous $0.1 \%$ TFA (mobile phase A) and $0.1 \%$ TFA in $84 \%$ aqueous acetonitrile (mobile phase B). The chromatography was carried on by linear gradient at room temperature, according to the following programme: from $0 \% \mathrm{~B}$ at time 0 to $60 \% \mathrm{~B}$ in 40 minutes, then to $90 \% \mathrm{~B}$ in 5 minutes, and at last to $0 \% \mathrm{~B}$ in 5 minutes; the equilibrium time between analyses was 5 minutes. LC-MS was performed operating both in (continuum) MS mode and in MS/MS mode for data dependent acquisition (DDA) of microcystin fragmentation spectra. The spectra were acquired at the speed of $1 \mathrm{scan} / \mathrm{sec}$. The source conditions were the following: capillary voltage: $3000 \mathrm{~V}$; cone voltage: $100 \mathrm{~V}$; Extractor: $0 \mathrm{~V}$; RF Lens: 60. Raw data were processed by MassLynx version 3.5 software (Waters, Manchester, UK). Mass spectrometer calibration was carried out on the basis of the multiple charged ions from fibrinopeptide-Glu introduced separately.

2.6.4. Ion Trap LC/ESI-MS/MS Analysis. Analyses were carried out using a LC/ESI-MS system, equipped with a quaternary pump Surveyor LC pump Plus, a Surveyor plus autosampler, and LCQ Advantage ion trap mass spectrometer with an electrospray ion source (ESI) (Thermo Fisher, Milan, Italy). Chromatographic separation was performed injecting $50 \mu \mathrm{L}$ sample volume on a $4 \mu \mathrm{m}$ particle $250 \times 3.0 \mathrm{~mm}$ Max RP $80 \AA$ Synergi stainless steel column (Phenomenex, Torrance, CA, USA), at $0.3 \mathrm{~mL} / \mathrm{min}$ flow rate, using $0.05 \%$ TFA in water as mobile phase A and $0.05 \%$ TFA in acetonitrile (ACN) as mobile phase B. The chromatography was carried out by linear gradient at room temperature, according to the following program: 2 minutes at $30 \% \mathrm{~B}$, then from $30 \% \mathrm{~B}$ at time 2 to $100 \% \mathrm{~B}$ in 16 minutes, holding on for 8 minutes, finally to $30 \% \mathrm{~B}$ in 3 minutes; the equilibrium time between runs was $12 \mathrm{~min}$. The mass spectrometer was periodically calibrated with standard solutions of Ultramark, caffeine, and Met-Arg-Phe-Ala peptide provided by the manufacturer. During the LC/ESI-MS/MS experiments, mass spectra were acquired in the negative ionisation mode; the spectrometer parameters were optimised by tuning on the $[\mathrm{M}-\mathrm{H}]$-ions of MC-LR and desMe-MC-LR e MC-LF, respectively, at $\mathrm{m} / z$ 993.3, 979.4 e 984.5. Tuning was performed at $0.3 \mathrm{~mL} / \mathrm{min}$ LC flow rate. The following experimental LC/ESI- MS/MS parameters were set: capillary temperature $300^{\circ} \mathrm{C}$, spray voltage $4.5 \mathrm{kV}$, and microscan number 3 . Further experimental conditions (collision energy, isolation width), and the diagnostic ions for MS/MS qualitative analysis, are also reported (Table 1). The LC/ESI-MS/MS analysis was carried out by monitoring the signals of the precursor ion $>$ product ion transitions (selected reaction monitoring, SRM mode) from the LC/ESI-MS/MS dataset of each MC; the data were acquired and processed using the Xcalibur software, version 1.3, from Thermo Fisher. Both blank samples and samples spiked at $1.0 \mathrm{ng} / \mathrm{g}$ with each MC were analysed. The chromatograms obtained extracting the precursor ion $\rightarrow$ main product ion transition (SRM) signals from the LC/ESIMS/MS dataset were integrated to calculate the calibration curves. Calibration curves for testing method linearity in solvent were calculated by linear regression, using standard solutions in methanol 10, 25, 50, 75, and $100 \mathrm{ng} / \mathrm{mL}$. During each working session, a blank reagent and blank and spiked samples were analyzed. The limits of quantification (LOQs) of the method are $0.5 \mathrm{ng} / \mathrm{g}$ for MC-RR, MC-LR, MC-YR, desMe-MC-RR, and desMe-MC-LR and $1.0 \mathrm{ng} / \mathrm{g}$ for MC-LW and MC-LF, showing that ion trap mass spectrometry is a very sensitive and reliable hyphenated technique for microcystin determination in seafood tissues.

\section{Results}

3.1. Lake Water Analysis. Three superficial water samples withdrawn in March 2009 from three lake stations during the bloom of $P$. rubescens and analyzed by Elisa immunoassay, gave values from 120 to $298 \mu \mathrm{g} / \mathrm{L}$ for total microcystin and from 0.5 to $0.7 \mu \mathrm{g} / \mathrm{L}$ for extracellular microcystin contents (Figure 2). In a superficial sample of the bloom in April, 2009, $14 \times 10^{9}$ cyanobacteria cell/L was counted. The total 


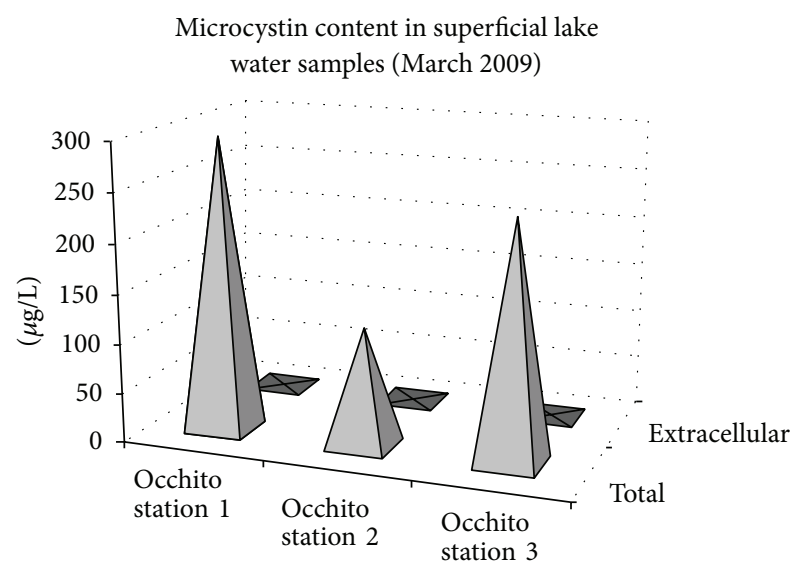

FIgURE 2: Total microcystin levels detected in 3 superficial samples from the 2009 Occhito bloom (March). The extracellular release was very low; the cell population was healthy and actively replicating.

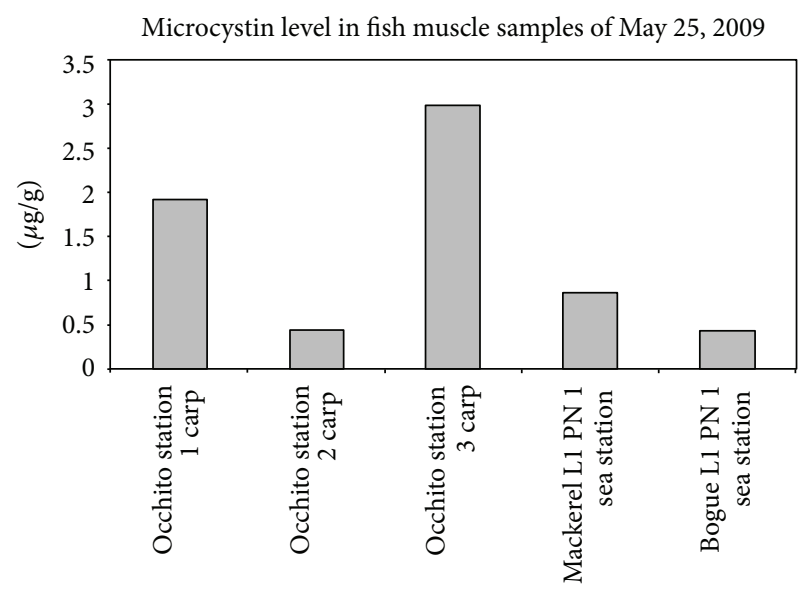

Figure 3: Microcystin level detected in fish muscle of marine and freshwater fish collected in May 2009. Note the highest level found in a freshly dead specimen (Cyprinus carpio) collected on the Occhito lakeshore near station 3 , whose death cause was not defined.

phosphorus mean level in the lake during years 2009-2010 was $43 \mu \mathrm{g} / \mathrm{L}$, typical value for mesotrophic condition [58].

3.2. Microcystin Concentration in Fish. The muscle of fish collected in May, 2009, analyzed by Elisa immunoassay showed microcystin contamination from 0.42 to $2.98 \mathrm{ng} / \mathrm{g}$ (Figure 3).

3.3. Sea Water Analysis. The sea water samples analyzed by Elisa immunoassay gave values from 0 up to $0.61 \mu \mathrm{g} / \mathrm{L}$ (May 2009). Three samples out of 36 analyzed (8\%) resulted negative. In 2009 monthly mean values of total microcystin concentration showed a peak at $0.38 \mu \mathrm{g} / \mathrm{L}$ (May 2009), decreasing progressively down to $0.03 \mu \mathrm{g} / \mathrm{L}$ in July (Figure 4 ). In 2010 monthly mean values showed a peak at $0.16 \mu \mathrm{g} / \mathrm{L}$ (January 2010) that decreased down to $0.01 \mu \mathrm{g} / \mathrm{L}$ in April (Figure 4).

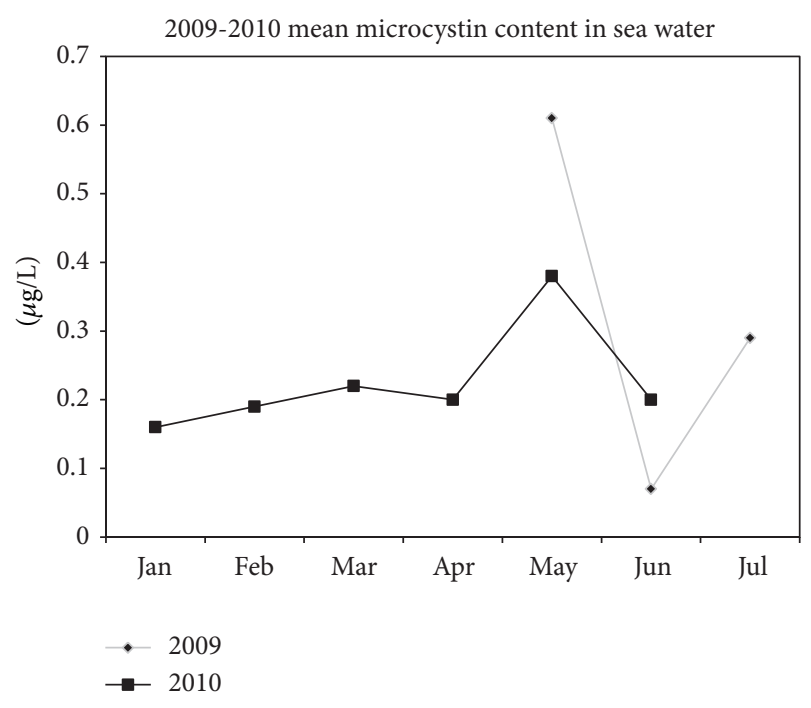

FIGURE 4: 2009-2010 monthly mean microcystin content in sea water sampled near the farmed mussels. Persistence of microcystins in sea water was observed until July 2009 and until June 2010.

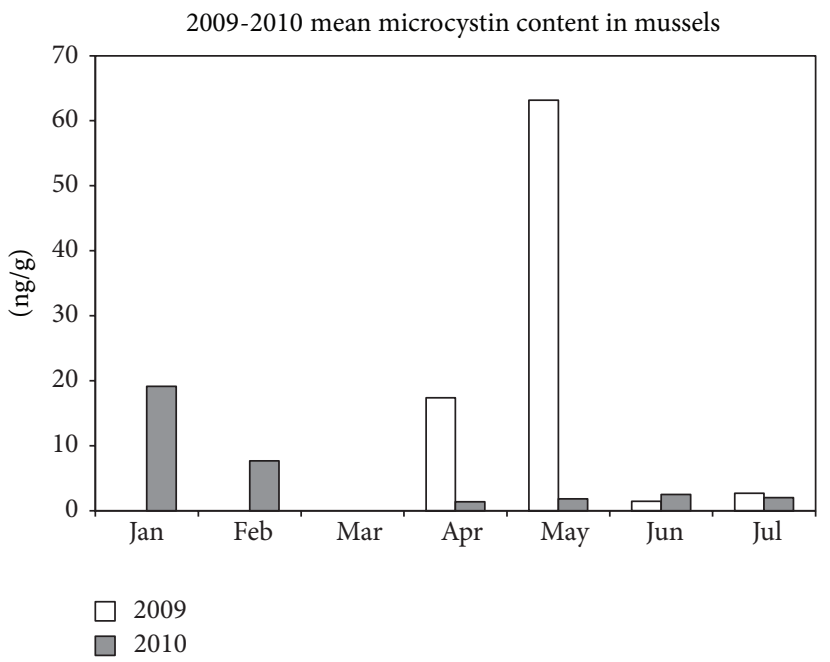

FIGURE 5: 2009-2010 monthly mean microcystin content detected in mussels from 13 farms near the Fortore estuary. The highest levels of toxin detection correspond to the 2009 extended bloom in Lake Occhito; the 2010 less extended bloom caused a lower contamination in mussels.

A few small, deteriorated trichomes of $P$. rubescens cells (mean cell number $15 \pm 10$ cells/L) were still visible in sea water in May 2009.

3.4. Mussel Analysis. The M. galloprovincialis mussels from sea farms were sampled and analyzed since April 2009 (Figure 5). The Elisa analyses showed a maximum microcystin concentration at $256 \mathrm{ng} / \mathrm{g}$ in 2009 (May 6), with a progressive decrease down to a minimum at $1.73 \mathrm{ng} / \mathrm{g}$ in July 1. Monthly mean values showed the highest concentration at $63.15 \mathrm{ng} / \mathrm{g}$ in May then decreasing down to $2.7 \mathrm{ng} / \mathrm{g}$ in July (Figure 5). In 2010 the highest value was detected in January 
TABLE 2: The concentration of desMe-MC-RR and MC-LR equivalents (ng/g) determined by LC/ESI-Q-ToF-MS/MS and ELISA in mussel samples collected along the sea coast close to Lake Lesina. nd: not detected.

\begin{tabular}{lcc}
\hline Sample and station & desMe-MC-RR & ELISA MC-LR eq. \\
\hline Mussels CV2 & 39 & 256 \\
Mussels L1 PN-1b & 8 & 28.23 \\
Mussels L1 PN-2a & 5 & 12.30 \\
Mussels CV1-c & 8 & 27.75 \\
Mussels CV2-h & 5 & 8.30 \\
Mussels CV2-p & nd $(<0.1)$ & 5.72 \\
\hline
\end{tabular}

$(27.75 \mathrm{ng} / \mathrm{g})$. Monthly mean values reached a maximum at $19.1 \mathrm{ng} / \mathrm{g}$ in January, with hidden decrease down to $1.38 \mathrm{ng} / \mathrm{g}$ in April, and a slow comeback to $2.5 \mathrm{ng} / \mathrm{g}$ in June (Figure 5). The Chamelea gallina benthic clams gave values from 1 up to $2.3 \mathrm{ng} / \mathrm{g}$ (May 2009). Eight mussel samples out of 75 analyzed (10.5\%) were not contaminated.

The analyses by MALDI-ToF/MS and LC/ESI-QToF/MS-MS were mainly addressed for a wide mass range screen for the groups of cyanotoxins present in the sample. Microcystins were found out to be the most abundant toxins; microcystin desMe-MC-RR, the marker variant typical of $P$. rubescens blooms, was the main toxin present in all water and seafood samples. The presence of microcystins was quantitatively determined in selected mussel samples (Table 2) by ion trap LC/ESI-MS/MS analysis. All the microcystins were completely separated by reversed phase HPLC on a C12 stationary phase column and unambiguously identified by at least 2 product ions produced in the MS/MS SRM mode on ion trap. The variant desMe-MC-RR was detected in mussel samples up to $39 \mathrm{ng} / \mathrm{g}$. Figure 6 shows the SRM chromatogram (base peak at $m / z$ 1004) of a mussel sample containing des-Me-MC-RR; the presence of the precursor ion and 2 product ions in MS/MS spectrum allows for unambiguous identification of this microcystin.

\section{Discussion}

In January 2009, Lake Occhito hosted an extended reddish bloom (lasting four months), of the toxic cyanobacterium P. rubescens. In 2009-2010 the general trend of P. rubescens population dynamics showed superficial stratification with blooms in winter and a population decrease from late May to early December. This behaviour is consistent with findings of Walsby et al. [66] for Lake Zurich, (Switzerland), Jacquet et al. [67] for Lake du Bourget (France), and Messineo et al. [68] for Lake Albano (Italy). The P. rubescens toxic production is marked by the main presence of the desMe-MC-RR variant [69]. In a contemporary study (2009) analyzing Occhito Lake water by MALDI-ToF/MS and LC-Q-ToF tandem mass spectrometry, several cyanotoxins were detected in cell extracts: desMe-MC-RR and MC-RR were the most abundant microcystin variants detected [57]. In our study, the analytical data from mussel samples showed the presence of high levels of microcystins, in direct relation with the temporal trend of bloom presence in lake surface waters. The origin of the toxin contamination in mussels was proved by the presence in the mussel tissue of the same marker variant desMe-MC-RR. As a consequence of microcystin contamination, in 2009, the local health authority prohibited mussel commerce, to prevent possible contamination of consumers. In autumnwinter 2010 the bloom rose again, but to a minor extent, and a lower mussel contamination occurred. Mussels and clams are mainly consumed as a crude dish or cooked according to traditional recipes. Microcystin content in mussels is not affected by boiling [70]. For an adult human weighing $60 \mathrm{~kg}$ and ingesting from 100 to $300 \mathrm{~g}$ serving of mussels, the microcystin level of $80 \%$ of mussel samples analyzed in 2009 and of $19 \%$ of mussel samples analyzed in 2010 was even 4fold in the first case and 3-fold in the second case, the recommended TDI value of $0.04 \mu / \mathrm{kg}$ body weight/day suggested by WHO [71]. The covalently bound portion of microcystins is not detectable by conventional organic solvent extraction methods and can represent up to $38-99 \%$ of the total microcystins contained within the tissues [72]. This may lead to considerable underestimation of total microcystins content and, consequently, of related human health risk, by some orders of magnitude $[45,73,74]$, because the bonded toxins during digestion are released in a toxically active form $[72,75]$. So, even the toxic values detected in this study could noticeably underestimate the real total microcystin content in mussel and fish samples tested. The presence of microcystin contamination in the farmed M. galloprovincialis of Lake Varano coasts represents a serious economic damage for local populations, because these farms produce one of the best qualitative seafood products in Italy [76].

The presence of microcystins in five out of five collected fish during the $P$. rubescens bloom suggests the need for further studies on ichthyic marine and freshwater fauna during these occurrences in Lake Occhito.

Until today, only microcystin contaminated fish muscle consumption was known to be a threat for human health $[35-39,77]$. Our study demonstrates that also contaminated farmed sea mussels may represent a new health risk to consumers and a cause of economic damage when inland waters, affected by toxic eutrophication and communicating with coastal sea waters, are not managed with specific remediation plans. The detected microcystin contamination in wild clams also raises the problem of possible transfer through the food chain to marine invertebrate predators (other molluscs, crabs, and crayfish). These in their turn may be preys of vertebrate predators fished for human consumption. Several recent studies detecting chemical contaminations (polychlorinated biphenyls, dioxins and furans, heavy metals) in southern Adriatic Sea ichthyic fauna have been performed [78, 79], but this is the first study planned on cyanotoxin presence till now and also the first study reporting the periodic accumulation of microcystins in farmed and wild marine mussels due to contamination by toxic freshwater blooms. Moreover, this study represents a model for food safety risk management, according to the law of European Union commission for consumer protection; indeed, test methods, both for rapid screening and for confirmation and quantification, were developed, to identify the cyanotoxins produced during a bloom, to profile and quantitate the main toxic compounds, 

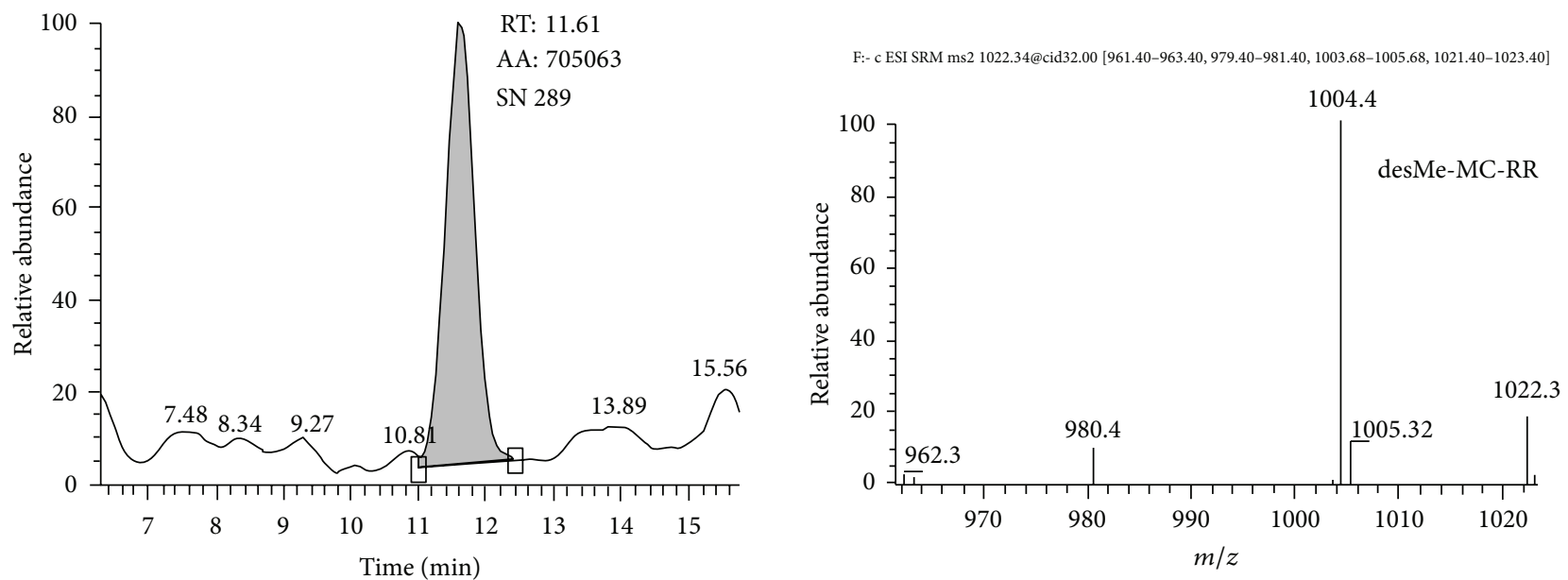

(a)
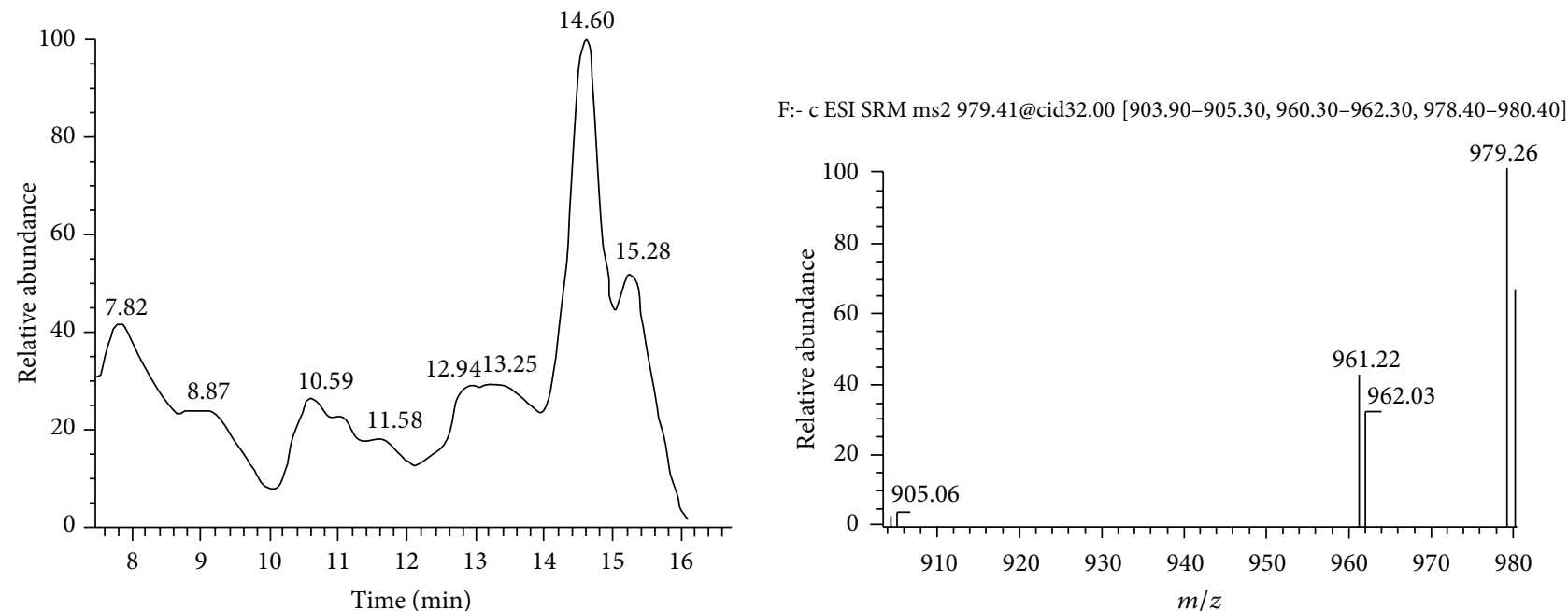

(b)

FIGURE 6: desMe-MC-RR detection in a contaminated mussel. The SRM ion trap LC/ESI-MS/MS chromatogram (base peak) of a mussel sample from Lake Lesina (CV-lc) containing desMe-MC-RR (upper graph.) and a blank sample (lower graph.); their respective MS/MS spectra are reported.

and then to trace the contamination from freshwaters to seafood. In the case of Lake Occhito, the availability of data about microcystin contamination allowed for health risk characterization and, consequently, risk evaluation, and proper communication to consumers and health authorities.

\section{Conflict of Interests}

The authors declare that there is no conflict of interests regarding the publication of this paper.

\section{References}

[1] I. R. Falconer, A. M. Beresford, and M. T. C. Runnegar, "Evidence of liver damage by toxin from a bloom of the blue-green alga, Microcystis aeruginosa," Medical Journal of Australia, vol. 1, no. 11, pp. 511-514, 1983.
[2] M. G. Teixeira, M. C. Costa, V. L. de Carvalho, M. D. S. Pereira, and E. Hage, "Gastroenteritis epidemic in the area of the Itaparica dam, Bahia, Brazil," Bulletin of the Pan American Health Organization, vol. 27, no. 3, pp. 244-253, 1993.

[3] R. M. Dawson, “The toxicology of microcystins,” Toxicon, vol. 36, no. 7, pp. 953-962, 1998.

[4] G. A. Codd, "Cyanobacterial toxins: occurrence, properties and biological significance," Water Science and Technology, vol. 32, no. 4, pp. 149-156, 1995.

[5] K. I. Harada and K. Tsuji, "Persistence and decomposition of hepatotoxic microcystins produced by cyanobacteria in natural environment," Journal of Toxicology, vol. 17, no. 3, pp. 385-403, 1998.

[6] E. M. Jochimsen, W. W. Carmichael, J. An et al., "Liver failure and death after exposure to microcystins at a hemodialysis center in Brazil," The New England Journal of Medicine, vol. 338, no. 13, pp. 873-878, 1998. 
[7] M. R. Prinsep, F. R. Caplan, R. E. Moore, G. M. L. Patterson, R. Honkanen, and A. L. Boynton, "Microcystin-la from a bluegreen alga belonging to the stigonematales," Phytochemistry, vol. 31, no. 4, pp. 1247-1248, 1992.

[8] C. J. Hastie, E. B. Borthwick, L. F. Morrison, G. A. Codd, and P. T. W. Cohen, "Inhibition of several protein phosphatases by a noncovalently interacting microcystin and a novel cyanobacterial peptide, nostocyclin," Biochimica et Biophysica Acta, vol. 1726, no. 2, pp. 187-193, 2005.

[9] C. MacKintosh, K. A. Beattie, S. Klumpp, P. Cohen, and G. A. Codd, "Cyanobacterial microcystin-LR is a potent and specific inhibitor of protein phosphatases 1 and $2 \mathrm{~A}$ from both mammals and higher plants," FEBS Letters, vol. 264, no. 2, pp. 187-192, 1990.

[10] S. M. F. O. Azevedo, W. W. Carmichael, E. M. Jochimsen et al., "Human intoxication by microcystins during renal dialysis treatment in Caruaru-Brazil," Toxicology, vol. 181-182, pp. 441446, 2002.

[11] K. Sivonen and G. Jones, "Cyanobacterial toxins," in Toxic Cyanobacteria in Water, I. Chorus and J. Bartram, Eds., pp. 41111, E and FN Spon, London, UK, 1999.

[12] F. Mwaura, A. O. Koyo, and B. Zech, "Cyanobacterial blooms and the presence of cyanotoxins in small high altitude tropical headwater reservoirs in Kenya," Journal of Water and Health, vol. 2, no. 1, pp. 49-57, 2004.

[13] M. Rojas, M. T. Nunez, and F. Zambrano, "Inhibitory effect of a toxic peptide isolated from a waterbloom of Microcystis sp. (cyanobacteria) on iron uptake by rabbit reticulocytes," Toxicon, vol. 28, no. 11, pp. 1325-1332, 1990.

[14] S. L. Ford, D. R. E. Abayasekara, S. J. Persaud, and P. M. Jones, "Role of phosphoprotein phosphatases in the corpus luteum: I. Identification and characterisation of serine/threonine phosphoprotein phosphatases in isolated rat luteal cells," Journal of Endocrinology, vol. 150, no. 2, pp. 205-211, 1996.

[15] S. B. Sayed, B. J. Whitehouse, and P. M. Jones, "Phosphoserine/ threonine phosphatases in the rat adrenal cortex: a role in the control of steroidogenesis?" Journal of Endocrinology, vol. 154, no. 3, pp. 449-458, 1997.

[16] M. Hernández, M. Macia, C. Padilla, and F. F. del Campo, "Modulation of human polymorphonuclear leukocyte adherence by cyanopeptide toxins," Environmental Research A, vol. 84, no. 1, pp. 64-68, 2000.

[17] T. Leiers, A. Bihlmayer, H. P. T. Ammon, and M. A. Wahl, "Ca2- and insulin-stimulating effect of the non-membrane permeable phosphatase-inhibitor microcystin-LR in intact insulinsecreting cells (RINm5F)," British Journal of Pharmacology, vol. 130, no. 6, pp. 1406-1410, 2000.

[18] H. Li, P. Xie, G. Li, L. Hao, and Q. Xiong, "In vivo study on the effects of microcystin extracts on the expression profiles of proto-oncogenes (c-fos, c-jun and c-myc) in liver, kidney and testis of male Wistar rats injected i.v. with toxins," Toxicon, vol. 53, no. 1, pp. 169-175, 2009.

[19] IARC, Ingested Nitrate and Nitrite and Cyanobacterial Peptide Toxins, vol. 94 of IARC Monographs on The Evaluation of Carcinogenic Risks to Humans, WHO-IARC, Lion, France, 2010.

[20] S. Z. Yu, "Drinking water and primary liver cancer," in Primary Liver Cancer, Z. Y. Tang, M. C. Wu, and S. S. Xia, Eds., pp. 30-37, Springer, Berlin, Germany, 1989.

[21] Y. Ueno, S. Nagata, T. Tsutsumi et al., "Detection of microcystins, a blue-green algal hepatotoxin, in drinking water sampled in Haimen and Fusui, endemic areas of primary liver cancer in China, by highly sensitive immunoassay," Carcinogenesis, vol. 17, no. 6, pp. 1317-1321, 1996.

[22] L. Zhou, H. Yu, and K. Chen, "Relationship between microcystin in drinking water and colorectal cancer," Biomedical and environmental sciences, vol. 15, no. 2, pp. 166-171, 2002.

[23] L. E. Fleming, C. Rivero, J. Burns et al., "Blue green algae (cyanobacterial) toxins, surface drinking water, and liver cancer in Florida," Harmful Algae, vol. 1, no. 2, pp. 57-168, 2002.

[24] Z. Svirčev, S. Krstić, M. Miladinov-Mikov, V. Baltić, and M. Vidović, "Freshwater cyanobacterial blooms and primary liver cancer epidemiological studies in Serbia," Journal of Environmental Science and Health C, vol. 27, no. 1, pp. 36-55, 2009.

[25] R. B. Fitzgeorge, I. A. Clark, and C. W. Keevil, "Routes of intoxication," in Detection Methods for Cyanobacterial Toxins, G. A. Codd, T. M. Jefferies, C. W. Keevil, and E. Potter, Eds., pp. 6974, The Royal Society of Chemistry, Cambridge, UK, 1994.

[26] P. F. Solter, G. K. Wollenberg, X. Huang, F. S. Chu, and M. T. Runnegar, "Prolonged sublethal exposure to the protein phosphatase inhibitor microcystin-LR results in multiple dosedependent hepatotoxic effects," Toxicological Sciences, vol. 44, no. 1, pp. 87-96, 1998.

[27] P. V. Zimba, L. Khoo, P. S. Gaunt, S. Brittain, and W. W. Carmichael, "Confirmation of catfish, Ictalurus punctatus (Rafinesque), mortality from Microcystis toxins," Journal of Fish Diseases, vol. 24, no. 1, pp. 41-47, 2001.

[28] P. V. Zimba, A. Camus, E. H. Allen, and J. M. Burkholder, "Cooccurrence of white shrimp, Litopenaeus vannamei, mortalities and microcystin toxin in a southeastern USA shrimp facility," Aquaculture, vol. 261, no. 3, pp. 1048-1055, 2006.

[29] M. A. Jewel, M. A. Affan, and S. Khan, "Fish mortality due to cyanobacterial bloom in an aquaculture pond in Bangladesh," Pakistan Journal of Biological Sciences, vol. 6, pp. 1046-1054, 2003.

[30] B. Ernst, S. J. Hoeger, E. O’Brien, and D. R. Dietrich, “Oral toxicity of the microcystin-containing cyanobacterium Planktothrix rubescens in European whitefish (Coregonus lavaretus)," Aquatic Toxicology, vol. 79, no. 1, pp. 31-40, 2006.

[31] E. Ito, A. Takai, F. Kondo, H. Masui, S. Imanishi, and K.I. Harada, "Comparison of protein phosphatase inhibitory activity and apparent toxicity of microcystins and related compounds," Toxicon, vol. 40, no. 7, pp. 1017-1025, 2002.

[32] J. Cazenave, D. A. Wunderlin, M. D. L. Á. Bistoni et al., "Uptake, tissue distribution and accumulation of microcystin-RR in Corydoras paleatus, Jenynsia multidentata and Odontesthes bonariensis. A field and laboratory study," Aquatic Toxicology, vol. 77, no. 4, p. 439, 2006.

[33] F. Tencalla and D. Dietrich, "Biochemical characterization of microcystin toxicity in rainbow trout (Oncorhynchus mykiss)," Toxicon, vol. 35, no. 4, pp. 583-595, 1997.

[34] W. J. Fischer and D. R. Dietrich, "Pathological and biochemical characterization of microcystin-induced hepatopancreas and kidney damage in carp," Toxicology and Applied Pharmacology, vol. 164, no. 1, pp. 73-81, 2000.

[35] V. Freitas de Magalhães, R. Moraes Soares, and S. M. F. O. Azevedo, "Microcystin contamination in fish from the Jacarepaguá Lagoon (Rio de Janeiro, Brazil): ecological implication and human health risk," Toxicon, vol. 39, no. 7, pp. 1077-1085, 2001.

[36] Z. A. Mohamed, W. W. Carmichael, and A. A. Hussein, "Estimation of microcystins in the freshwater fish Oreochromis niloticus in an Egyptian fish farm containing a Microcystis 
bloom," Environmental Toxicology, vol. 18, no. 2, pp. 137-141, 2003.

[37] J. Chen, P. Xie, D. Zhang, Z. Ke, and H. Yang, "In situ studies on the bioaccumulation of microcystins in the phytoplanktivorous silver carp (Hypophthalmichthys molitrix) stocked in Lake Taihu with dense toxic Microcystis blooms," Aquaculture, vol. 261, no. 3, pp. 1026-1038, 2006.

[38] S. A. Wood, L. R. Briggs, J. Sprosen et al., "Changes in concentrations of microcystins in rainbow trout, freshwater mussels, and cyanobacteria in Lakes Rotoiti and Rotoehu," Environmental Toxicology, vol. 21, no. 3, pp. 205-222, 2006.

[39] M. Bruno, P. Gallo, V. Messineo, and S. Melchiorre, "Risk associated with microcystin presence in the environment: the case of an Italian lake (Lake Vico, central Italy)," International Journal of Environmental Protection, vol. 2, no. 4, pp. 34-41, 2012.

[40] E. E. Prepas, B. G. Kotak, L. M. Campbell, J. C. Evans, S. E. Hrudey, and C. F. B. Holmes, "Accumulation and elimination of cyanobacterial hepatotoxins by the freshwater clam Anodonta grandis simpsoniana," Canadian Journal of Fisheries and Aquatic Sciences, vol. 54, no. 1, pp. 41-46, 1997.

[41] M. F. Watanabe, H.-D. Park, F. Kondo, K.-I. Harada, H. Hayashi, and T. Okino, "Identification and estimation of microcystins in freshwater mussels," Natural Toxins, vol. 5, no. 1, pp. 31-35, 1997.

[42] H. A. Vanderploeg, J. R. Liebig, W. W. Carmichael et al., "Zebra mussel (Dreissena polymorpha) selective filtration promoted toxic Microcystis blooms in Saginaw Bay (Lake Huron) and Lake Erie," Canadian Journal of Fisheries and Aquatic Sciences, vol. 58, no. 6, pp. 1208-1221, 2001.

[43] A. Yokoyama and H. D. Park, "Mechanism and prediction for contamination of freshwater bivalves (Unionidae) with the cyanobacterial toxin microcystin in hypereutrophic Lake Suwa, Japan," Environmental Toxicology, vol. 17, no. 5, pp. 424-433, 2002.

[44] J. Chen and P. Xie, "Seasonal dynamics of the hepatotoxic microcystins in various organs of four freshwater bivalves from the large eutrophic Lake Taihu of subtropical China and the risk to human consumption," Environmental Toxicology, vol. 20, no. 6, pp. 572-584, 2005.

[45] L. Peng, Y. Liu, W. Chen, L. Liu, M. Kent, and L. Song, "Health risks associated with consumption of microcystincontaminated fish and shellfish in three Chinese lakes: significance for freshwater aquacultures," Ecotoxicology and Environmental Safety, vol. 73, no. 7, pp. 1804-1811, 2010.

[46] V. M. Vasconcelos, "Uptake and depuration of the heptapeptide toxin microcystin-LR in Mytilus galloprovincialis," Aquatic Toxicology, vol. 32, no. 2-3, pp. 227-237, 1995.

[47] M. A. Miller, R. M. Kudela, A. Mekebri et al., "Evidence for a novel marine harmful algal bloom: cyanotoxin (microcystin) transfer from land to sea otters," PLoS ONE, vol. 5, no. 9, Article ID e12576, pp. 1-11, 2010.

[48] T. Lindholm, J. E. Eriksson, and J. A. O. Meriluoto, “Toxic cyanobacteria and waterquality problems-examples from a eutrophic lake on Åland, South West Finland," Water Research, vol. 23, no. 4, pp. 481-486, 1989.

[49] Á. Amorim and V. M. Vasconcelos, "Dynamics of microcystins in the mussel Mytilus galloprovincialis," Toxicon, vol. 37, no. 7, pp. 1041-1052, 1999.

[50] J. E. Eriksson, J. A. O. Meriluoto, and T. Lindholm, "Accumulation of a peptide toxin from the cyanobacterium Oscillatoria agardhii in the freshwater mussel Anadonta cygnea," Hydrobiologia, vol. 183, no. 3, pp. 211-216, 1989.
[51] A. Yokoyama and H. D. Park, "Depuration kinetics and persistence of the cyanobacterial toxin microcystin-LR in the freshwater bivalve Unio douglasiae," Environmental Toxicology, vol. 18, no. 1, pp. 61-67, 2003.

[52] S. Fernandes, M. Welker, and V. M. Vasconcelos, "Changes in the GST activity of the mussel Mytilus galloprovincialis during exposure and depuration of microcystins," Journal of Experimental Zoology A, vol. 311, no. 3, pp. 226-230, 2009.

[53] V. M. Vasconcelos, C. Wiegand, and S. Pflugmacher, "Dynamics of glutathione-S-transferases in Mytilus galloprovincialis exposed to toxic Microcystis aeruginosa cells, extracts and pure toxins," Toxicon, vol. 50, no. 6, pp. 740-745, 2007.

[54] V. M. Vasconcelos, "Toxic cyanobacteria (blue-green algae) in Portuguese fresh waters," Archiv fur Hydrobiologie, vol. 130, no. 4, pp. 439-451, 1994.

[55] K. Vareli, E. Zarali, G. S. A. Zacharioudakis et al., "Microcystin producing cyanobacterial communities in Amvrakikos Gulf (Mediterranean Sea, NW Greece) and toxin accumulation in mussels (Mytilus galloprovincialis)," Harmful Algae, vol. 15, pp. 109-118, 2012.

[56] K. Vareli, W. Jaeger, A. Touka, S. Frillingos, E. Briasoulis, and I. Sainis, "Hepatotoxic seafood poisoning (HSP) due to microcystins: a threat from the ocean?" Marine Drugs, vol. 11, pp. 2751-2768, 2013.

[57] S. Bogialli, F. Nigro Di Gregorio, L. Lucentini et al., "Management of a toxic cyanobacterium bloom (Planktothrix rubescens) affecting an Italian drinking water basin: a case study," Environmental Science and Technology, vol. 47, pp. 574-583, 2013.

[58] L. Landner and U. Wahlgren, Eutrophication of Lakes and Reservoirs in Warm Climates, Environmental Health Series, WHO, Regional Office for Europe, Copenhagen, Denmark, 1988.

[59] H. Utermöhl, "Neue Wege in der quantitativen Earfassung des Planktons (mit besonderer Berücksichtigung des ultraplanktons)," Verhandlungen der Internationale Vereinigung für Limnologie, vol. 5, pp. 567-596, 1931.

[60] J. W. G. Lund, C. Kipling, and E. D. Le Cren, “The inverted microscope method of estimating algal numbers and the statistical basis of estimations by counting," Hydrobiologia, vol. 11, no. 2, pp. 143-170, 1958.

[61] D. Lambert and W. Maher, "An evaluation of the efficiency of the alkaline persulphate digestion method for the determination of total phosphorus in turbid waters," Water Research, vol. 29, no. 1, pp. 7-9, 1995.

[62] J. Murphy and J. P. Riley, "A modified single solution method for the determination of phosphate in natural waters," Analytica Chimica Acta, vol. 27, pp. 31-36, 1962.

[63] J. A. O. Meriluoto and J. E. Eriksson, "Rapid analysis of peptide toxins in cyanobacteria," Journal of Chromatography A, vol. 438, pp. 93-99, 1988.

[64] B. Ernst, B. Hitzfeld, and D. Dietrich, "Presence of Planktothrix sp. and cyanobacterial toxins in Lake Ammersee, Germany and their impact on whitefish (Coregonus lavaretus L.)," Environmental Toxicology, vol. 16, no. 6, pp. 483-488, 2001.

[65] J. S. Metcalf, P. Hyenstrand, K. A. Beattie, and G. A. Codd, "Effects of physicochemical variables and cyanobacterial extracts on the immunoassay of microcystin-LR by two ELISA kits," Journal of Applied Microbiology, vol. 89, no. 3, pp. 532-538, 2000.

[66] A. E. Walsby, A. Avery, and F. Schanz, "The critical pressures of gas vesicles in Planktothrix rubescens in relation to the depth of 
winter mixing in Lake Zurich, Switzerland," Journal of Plankton Research, vol. 20, no. 7, pp. 1357-1375, 1998.

[67] S. Jacquet, J. F. Briand, C. Leboulanger et al., "The proliferation of the toxic cyanobacterium Planktothrix rubescens following restoration of the largest natural French lake (Lac du Bourget)," Harmful Algae, vol. 4, no. 4, pp. 651-672, 2005.

[68] V. Messineo, D. Mattei, S. Melchiorre et al., "Microcystin diversity in a Planktothrix rubescens population from Lake Albano (Central Italy)," Toxicon, vol. 48, no. 2, pp. 160-174, 2006.

[69] M. Barco, C. Flores, J. Rivera, and J. Caixach, "Determination of microcystin variants and related peptides present in a water bloom of Planktothrix (Oscillatoria) rubescens in a Spanish drinking water reservoir by LC/ESI-MS," Toxicon, vol. 44, no. 8, pp. 881-886, 2004.

[70] J. Morais, M. Augusto, A. P. Carvalho, M. Vale, and V. M. Vasconcelos, "Cyanobacteria hepatotoxins, microcystins: bioavailability in contaminated mussels exposed to different environmental conditions," European Food Research and Technology, vol. 227, no. 3, pp. 949-952, 2008.

[71] I. Chorus and J. Bartram, Toxic Cyanobacteria in Water: A Guide to Their Public Health Consequences, Monitoring and Management, E \& FN Spon, London, UK, 1999, on behalf of the World Health Organization, Geneva, Switzerland.

[72] J. L. Smith, K. L. Schulz, P. V. Zimba, and G. L. Boyer, "Possible mechanism for the foodweb transfer of covalently bound microcystins," Ecotoxicology and Environmental Safety, vol. 73, no. 5, pp. 757-761, 2010.

[73] J. L. Ott and W. W. Carmichael, "LC/ESI/MS method development for the analysis of hepatotoxic cyclic peptide microcystins in animal tissues," Toxicon, vol. 47, no. 7, pp. 734-741, 2006.

[74] J. P. Berry, E. Lee, K. Walton, A. E. Wilson, and F. Bernal-Brooks, "Bioaccumulation of microcystins by fish associated with a persistent cyanobacterial bloom in Lago de Patzcuaro (Michoacan, Mexico)," Environmental Toxicology and Chemistry, vol. 30, no. 7, pp. 1621-1628, 2011.

[75] F. Kondo, Y. Ikai, H. Oka et al., "Formation, characterization, and toxicity of the glutathione and cysteine conjugates of toxic heptapeptide microcystins," Chemical Research in Toxicology, vol. 5, no. 5, pp. 591-596, 1992.

[76] T. Tolon, S. Pelosi, M. Franchi, and S. Marolla, "Evolution of shellfish breeding in Varano Lagoon," E.U. Journal of Fisheries \& Aquatic Sciences, vol. 18, no. 3-4, pp. 469-474, 2001.

[77] V. Messineo, S. Melchiorre, A. di Corcia, P. Gallo, and M. Bruno, "Seasonal succession of Cylindrospermopsis raciborskii and Aphanizomenon ovalisporum blooms with cylindrospermopsin occurrence in the volcanic Lake Albano, Central Italy," Environmental Toxicology, vol. 25, no. 1, pp. 18-27, 2010.

[78] C. Della Torre, T. Petochi, I. Corsi et al., "DNA damage, severe organ lesions and high muscle levels of As and $\mathrm{Hg}$ in two benthic fish species from a chemical warfare agent dumping site in the Mediterranean Sea," Science of the Total Environment, vol. 408, no. 9, pp. 2136-2145, 2010.

[79] M. M. Storelli, G. Barone, V. G. Perrone, and R. GiacominelliStuffler, "Polychlorinated biphenyls (PCBs), dioxins and furans (PCDD/Fs): occurrence in fishery products and dietary intake," Food Chemistry, vol. 127, no. 4, pp. 1648-1652, 2011. 

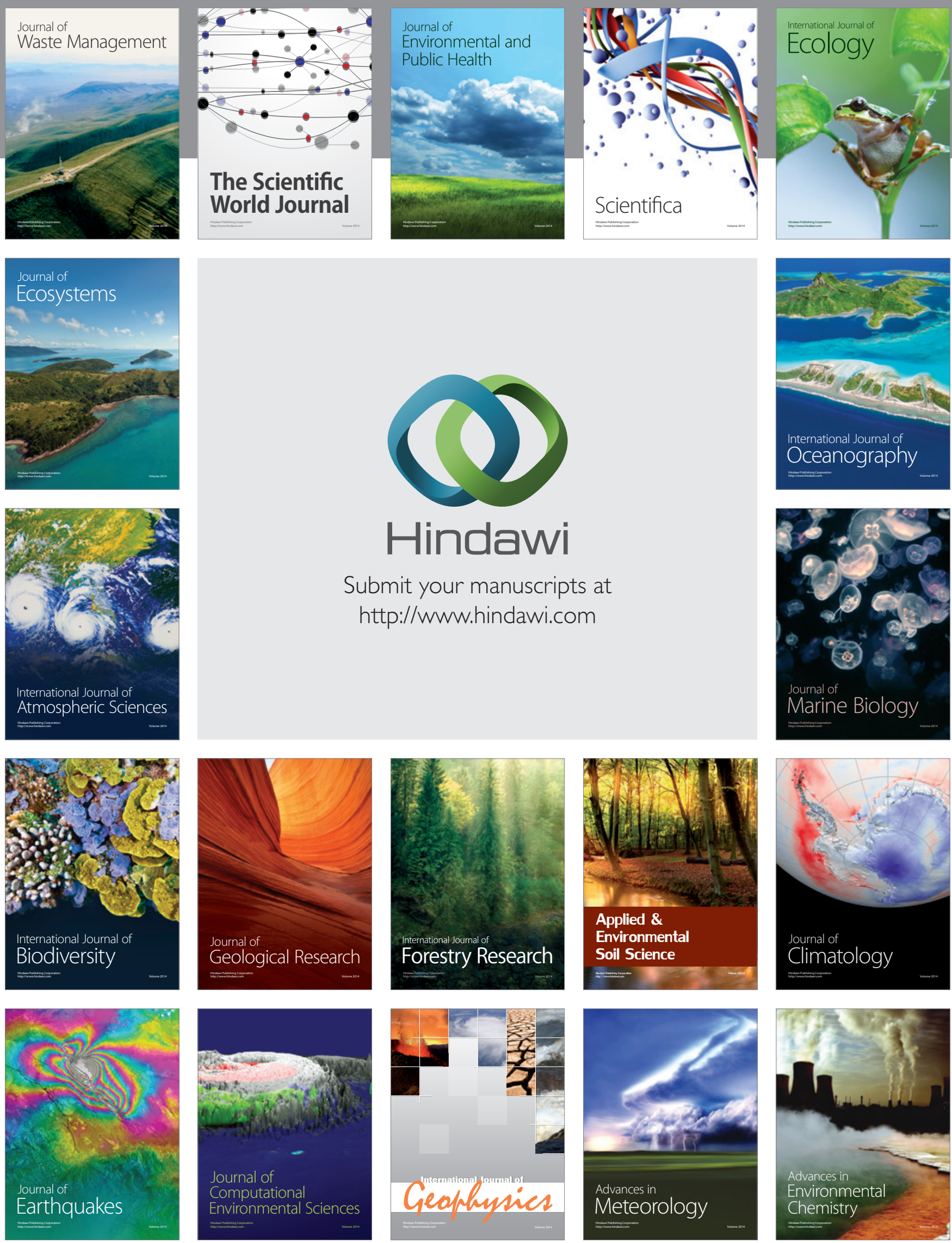